Research Article

\title{
Crosslinguistic Intelligibility of Russian and German Speech in Noisy Environment
}

\author{
Rodmonga Potapova and Maria Grigorieva \\ Institute of Applied and Mathematical Linguistics, Moscow State Linguistic University, Ostozhenka 38, Moscow 119034, Russia \\ Correspondence should be addressed to Maria Grigorieva; ivanovam112@mail.ru
}

Received 19 June 2016; Revised 26 January 2017; Accepted 26 February 2017; Published 13 July 2017

Academic Editor: Alexey Karpov

Copyright ( 2017 Rodmonga Potapova and Maria Grigorieva. This is an open access article distributed under the Creative Commons Attribution License, which permits unrestricted use, distribution, and reproduction in any medium, provided the original work is properly cited.

\begin{abstract}
This paper discusses the results of the pilot experimental research dedicated to speech recognition and perception of the semantic content of the utterances in noisy environment. The experiment included perceptual-auditory analysis of words and phrases in Russian and German (in comparison) in the same noisy environment: various (pink and white) types of noise with various levels of signal-to-noise ratio. The statistical analysis showed that intelligibility and perception of the speech in noisy environment are influenced not only by noise type and its signal-to-noise ratio, but also by some linguistic and extralinguistic factors, such as the existing redundancy of a particular language at various levels of linguistic structure, changes in the acoustic characteristics of the speaker while switching from one language to another one, the level of speaker and listener's proficiency in a specific language, and acoustic characteristics of the speaker's voice.
\end{abstract}

\section{Introduction}

Speech intelligibility and speech recognition are important and trending topics of research in various fields of science: Linguistics, Medicine, Electrical Engineering, and Information Technology. Speech recognition process is investigated from different sides, as only an integrated approach could lead to a better understanding of this process. One of research directions is study of biological and neurologic mechanisms of speech perception [1-5]. Another research area is intelligibility of synthesized speech in noise [6, 7]. Much attention is paid to development of algorithms improving speech intelligibility in noise [8-10].

Study of listener's specifics on the process of speech recognition showed that music training affects positively speechin-noise perception [11, 12]. Another important and rather controversial topic is perception of accented speech in noise by native and nonnative listeners; thus the research [13] revealed that native listeners were able to percept the test material at the same level regardless of the accent of the speaker while previous studies $[14,15]$ showed that speech of native speakers was generally found by native listeners more intelligible than speech of nonnative ones; nonnative listeners showed a trend of better perception of speech produced by speakers from the same language environment as themselves, that is, those having familiar accent $[16,17]$.

In Russia studies of speech characteristics and speech intelligibility and recognition in noise environment started in the middle of 20th century ([18-20], etc.). Experiments $[19,20]$ on word intelligibility for Russian speech against white and pink noise with levels of signal-to-noise ratio of $0 \mathrm{~dB}$ and lower showed different results: according to [19] the results for these two types of noise were very similar, while according to [20] word intelligibility for speech against white noise was higher. At the end of 20th century a major study of speech perception was carried out in white noise with various levels of signal-to-noise ratio [21], which investigated influence of different factors on Russian speech recognition: natural versus synthesized speech, different parts of speech, number of syllables in the word, place of stress, different types of phonemes, and so forth, which resulted in the range of the factors, which actually have influence on speech perception and recognition in noise environment and the level of influence of each of these factors. Another study [22] investigated changes of speaker characteristics (such as voice pitch, tempo of speech, voice strength) in the conditions of 
switching from a native (Russian) language to a foreign one (English). The latest researches were focused on cognitive mechanisms of semantic content decoding of Russian speech in noise $[23,24]$, which demonstrated that dialogs have better intelligibility than monologs and reading, and such factors as background knowledge of listeners about the topic of the conversation and their general interest, as well as emotional level of the speaker, also influenced the process of speech perception.

The current research studies perception of native (Russian) and nonnative (German) speech in noisy environment (pink and white types of noise were chosen for the experiment) focuses on the following aims:

(1) To identify the effect of the tested types of noise with various levels of signal-to-noise ratio (in comparison) on speech perception;

(2) To identify effects of linguistic and extralinguistic factors on speech perception in noisy environment.

\section{Method and Experiment}

Our pilot research included perceptual-auditory analysis at various levels of linguistic structure of speech utterances in Russian and German (in comparison) in the same noisy environment: various (pink and white) types of noise with various levels of signal-to-noise ratio as well as effects of linguistic and extralinguistic factors on speech perception in noisy environment.

The research material of the study was a specially composed (according to the method of Potapova [25, 26]) ad hoc corpus of words and phrases in Russian and German in realizations of Russian and German native speakers, which were mixed with various (pink and white) types of noise with various levels of signal-to-noise ratio $(0 \mathrm{~dB},-3 \mathrm{~dB},-6 \mathrm{~dB}$, $-9 \mathrm{~dB}$, and $-12 \mathrm{~dB}$ ). The material allowed analyzing of protection and intelligibility degrees at acoustic, phonetic, syntactic, and lexical levels of linguistic structure.

The following requirements for development of the ad hoc research material were stated:

(1) Test phrases should be grammatically and semantically linked and consist of words which exist in both languages;

(2) Various types of consonants and vowels should be represented in the test phrases;

(3) Acoustic realization of the chosen types of consonants and vowels should be similar and comparable in both languages;

(4) Comparable (by place and manner of articulation) consonants and vowels should be in identical positions in a syllable (for all test words and phrases in Russian and German);

(5) The rhythmic scheme of test words and phrases should be identical for both languages;

(6) Combinations with various types of vowels in stressed position in the first syllable (with regard to unilateral
TABLE 1: Test phrases for experiment.

\begin{tabular}{|c|c|c|}
\hline \multirow{2}{*}{$\mathrm{N}$} & \multicolumn{2}{|c|}{ Analyzed languages } \\
\hline & Russian & German \\
\hline 1 & $\begin{array}{c}\text { Баба била Борю } \\
\text { ['babə 'bilə 'borju] } \\
\text { (Eng.: Woman beat Borya) }\end{array}$ & $\begin{array}{c}\text { Barby bittet Boris } \\
\text { ['barbi 'bitət 'bo:ris] } \\
\text { (Eng.: Barby asks Boris) }\end{array}$ \\
\hline 2 & $\begin{array}{c}\text { Папа пишет Поле } \\
\text { ['papə 'pifət 'polje] } \\
\text { (Eng.: Father writes to Polya) }\end{array}$ & $\begin{array}{c}\text { Papa spielte Poker } \\
\text { ['pa:pa 'Spi:Itə 'po:ke] } \\
\text { (Eng.: Father played poker) }\end{array}$ \\
\hline 3 & $\begin{array}{c}\text { Занят Зинин зонтик } \\
\text { ['zanjat 'zinin 'zontik] } \\
\text { (Eng.: Zina's umbrella is booked) }\end{array}$ & $\begin{array}{c}\text { Sara sitzt am Sofa } \\
\text { ['za:ra 'zitst am 'zo:fa] } \\
\text { (Eng.: Sara is sitting on the } \\
\text { sofa) }\end{array}$ \\
\hline 4 & $\begin{array}{c}\text { Саша сито сушит } \\
\text { ['sa/ə 'sitə 'suJit] } \\
\text { (Eng.: Sasha dries sieve) } \\
\end{array}$ & $\begin{array}{c}\text { Sascha schickte Schuhe } \\
\text { ['sa: a 'Ji:ktə 'fu:ə] } \\
\text { (Eng.: Sasha sent shoes) }\end{array}$ \\
\hline 5 & $\begin{array}{c}\text { Мама Милу моет } \\
\text { ['mamə 'milu 'mojet] } \\
\text { (Eng.: Mother washes Mila) }\end{array}$ & $\begin{array}{c}\text { Mama mietet Molle } \\
\text { ['ma:ma 'mi:tət 'molə] } \\
\text { (Eng.: Mother helps Molle) }\end{array}$ \\
\hline
\end{tabular}

distribution) should be tested for each type of consonants.

According to the requirements of the research material the following test phrases were formulated (see Table 1: analyzed syllables are bold in the table; hereafter the system of IPA was used for transcriptions).

Each phrase consists of 3 words, having in the first stressed syllable a combination of the tested type of consonant with one of the tested types of vowels. Since pronunciation norms of the German language require voicing the voiceless fricative consonant " $\mathrm{s}$ " preceding a vowel, speakers were instructed to pronounce this sound as a voiceless one in the word "Sascha."

Speakers, who took part in the study, were native speakers of the literary Russian language without prominent dialectal features of pronunciation, speaking also German (50\%) and being native speakers of the literary German language without prominent dialectal features of pronunciation, speaking also Russian (50\%). The level of knowledge of foreign language of all speakers was the same, B2-C1, which was tested according to the system developed by the Council of Europe [27]. 50\% of speakers were women (native Russian speakers and native German speakers) and 50\% were men (native Russian speakers and native German speakers).

Each speaker read aloud test phrases and isolated words from phrases three times each. Thus, the total number of obtained realizations of the test words and phrases totaled 480; the total number of realizations for a single speaker was 120 (60 in Russian and 60 in German).

All test words and phrases were combined into 2 tables (in Russian and in German). The order of words and phrases was random and differed for different speakers. All test words and phrases were read with the intonation of the completed narrative, followed by a pause.

Audio recording of the research material was conducted in a specially equipped room, preventing foreign interference and noise: an anechoic chamber of the Institute of Applied 
TABLE 2: Answer table for listeners.

\begin{tabular}{|c|c|c|c|c|c|c|}
\hline \multirow{2}{*}{$\begin{array}{l}\text { \# of } \\
\text { phonogram }\end{array}$} & \multicolumn{2}{|c|}{$\begin{array}{l}\text { Do you hear a speech signal? (mark } \\
\text { the corresponding cell with «X») }\end{array}$} & \multicolumn{3}{|c|}{$\begin{array}{l}\text { What is the utterance language? } \\
\text { (mark the corresponding cell with «x») }\end{array}$} & \multirow{2}{*}{$\begin{array}{c}\text { Write down everything, } \\
\text { you have heard (in } \\
\text { Russian) }\end{array}$} \\
\hline & Yes & No & Russian & German & Do not know & \\
\hline \multicolumn{7}{|l|}{1} \\
\hline \multicolumn{7}{|l|}{2} \\
\hline \multicolumn{7}{|l|}{$\vdots$} \\
\hline$n$ & & & & & & \\
\hline
\end{tabular}

and Mathematical Linguistics of Moscow State Linguistic University.

Two samples of noise (white and pink) were generated using the program Cool Edit Pro 2.0. for mixing them with audio records of the test words and phrases realizations.

Each speech segment was mixed with white and pink noise with various levels of signal-to-noise ratio: $0 \mathrm{~dB},-3 \mathrm{~dB}$, $-6 \mathrm{~dB},-9 \mathrm{~dB}$, and $-12 \mathrm{~dB}$. Thus, for each spoken realization of the test material 10 variants of mixed signals were obtained, 4800 samples in total, plus 150 phonograms containing only noise (75 with white noise and 75 with pink noise). The total number of phonograms for the experiment was 4950 .

The number of listeners was 21: 6 males and 15 females, 19-21 y.o., native speakers of the Russian language without prominent dialectal features of pronunciation with normal hearing, who have a command of English at level B2-C1 (which was tested on the system developed by the Council of Europe [27]). Some of them (12 listeners) are proficient in German at level B1-B2 and some (9 listeners) do not know German at all.

All phonograms were numbered randomly for presentation to each listener: total number of rotation variants was 11 .

Listeners have to listen to phonograms according to their sequence numbers in the proposed rotation variant and to write down the answers for each of them in the table (see example of the answer table in the Table 2).

They could listen to each phonogram as many times they wanted. Each half an hour there were short breaks. Work time per day did not exceed 4 hours. The perception test run during 2 days: total work time for each listener was 8 hours.

The total number of played phonograms was 23085. The total number of played phonograms, which contained only noise, was 727 .

The total number of played phonograms, containing speech signal (test words and phrases mixed with noise), was 22358 (the share of phonograms with white and pink noise types made up $50 \%$ each).

These calculations indicate that the size of the base of played phonograms is sufficient to ensure reliable and stable quality of the data.

A summary table with quantitative description of the experiment is presented in Table 3.

We calculated statistical sampling error for the findings to prove the observed tendencies statistically. The statistical sampling error was calculated using the following formula [28]:

$$
E=Z_{\alpha / 2} \sqrt{\frac{p q}{n}}
$$

TABLE 3: Quantitative description of the experiment.

\begin{tabular}{|c|c|c|}
\hline $\mathrm{N}$ & Characteristics & Number \\
\hline 1 & $\begin{array}{l}\text { Research material: number of words and phrases } \\
\text { in Russian }\end{array}$ & 20 \\
\hline 2 & $\begin{array}{l}\text { Research material: number of words and phrases } \\
\text { in German }\end{array}$ & 20 \\
\hline 3 & $\begin{array}{c}\text { Research material: number of words and phrases } \\
\text { in Russian and German }\end{array}$ & 40 \\
\hline 4 & Number of speakers & 4 \\
\hline 5 & $\begin{array}{c}\text { Number of realizations of test words and phrases } \\
\text { in Russian and German per one speaker }\end{array}$ & 120 \\
\hline 6 & $\begin{array}{l}\text { Total number of realizations (phonograms) of } \\
\text { test words and phrases in Russian and German }\end{array}$ & 480 \\
\hline 7 & Number of tested types of noise & 2 \\
\hline 8 & $\begin{array}{l}\text { Number of tested levels of signal-to-noise ratio } \\
\text { for each type of noise }\end{array}$ & 5 \\
\hline 9 & $\begin{array}{l}\text { Number of phonograms for perceptual-auditory } \\
\text { analysis, which contain speech signal (mixes of } \\
\text { test words and phrases with noise) }\end{array}$ & 4800 \\
\hline 10 & $\begin{array}{l}\text { Number of phonograms for perceptual-auditory } \\
\text { analysis, which contain only noise }\end{array}$ & 150 \\
\hline 11 & $\begin{array}{l}\text { Total number of phonograms for } \\
\text { perceptual-auditory analysis }\end{array}$ & 4950 \\
\hline 12 & Number of listeners & 21 \\
\hline 13 & Number of auditions, containing only noise & 727 \\
\hline 14 & $\begin{array}{c}\text { Total number of auditions, containing speech } \\
\text { signal (mixes of test words and phrases with } \\
\text { noise) }\end{array}$ & 22358 \\
\hline 15 & Total number of auditions & 23085 \\
\hline
\end{tabular}

where $E$ is the statistical sampling error, $Z_{\alpha / 2}$ is a $z$-value with a given confidence probability: in our case $Z_{\alpha / 2}=1.96$ or a confidence level of 95\%, pq is dispersion of an alternative characteristic (dispersion of the sample share): in our case, as the sample share is unknown, the maximum value $p q=0,25$ is taken [29], and $n$ is the sample size.

\section{Discussion}

The working hypothesis of the study was as follows: speech recognition (detection of speech in noise and identification of the utterance language) and perception of the semantic content of the utterance in the variable noisy environment are influenced by the type of noise and the signal-to-noise ratio, as well as by some of linguistic and extralinguistic factors. These factors are the existing redundancy of a particular 




FIGURE 1: Influence of the signal-to-noise ratio on detection of speech signal in noise.

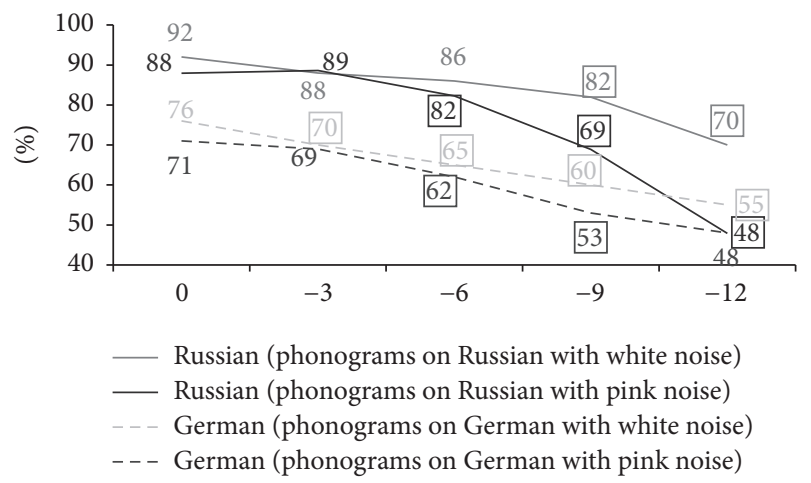

FIGURE 2: Recognition of the utterance language: comparison of Russian and German in noisy environment (with various types of noise and various levels of signal-to-noise ratio).

language at various levels of linguistic structure, changes in the acoustic characteristics of the speaker while switching from one language to another one, the speaker and listener's level of proficiency in a specific language, and acoustic characteristics of the speaker's voice.

The experiment showed that within the corpus of the research material pink noise provides better protection of the utterance than white noise at equal integral level of signal-to-noise ratio (for all tested levels) in terms of the following indicators: detection of speech signal in noise (see Figure 1), correct identification of the utterance language (see Figure 2), and correct perception of the semantic content of the utterance. On Figures 1 and 2 statistically significantly higher (at the level of 95\%) values in relation to the previous higher level of signal-to-noise ratio are marked with a frame.

The lower the level of signal-to-noise ratio (the higher the level of noise over the level of the desired signal), the higher the difference of efficiency degree between pink and white types of noise, reaching its maximum at the lowest tested signal-to-noise ratio $(-12 \mathrm{~dB})$ : while assessing detection of speech signal in noise, the efficiency of white noise masking is $\sim 4.7$ times lower as compared to pink noise. This result corresponds to findings observed in [20].

Detection of the utterance in noise also depends on level of speaker and listener's proficiency in a specific language, as well as on utterance language. Thus, for listeners, who are native Russian speakers, a higher score of detection of utterance in noise was shown for utterances in German, pronounced by native German speakers, than for utterances in Russian, pronounced by native Russian speakers (see

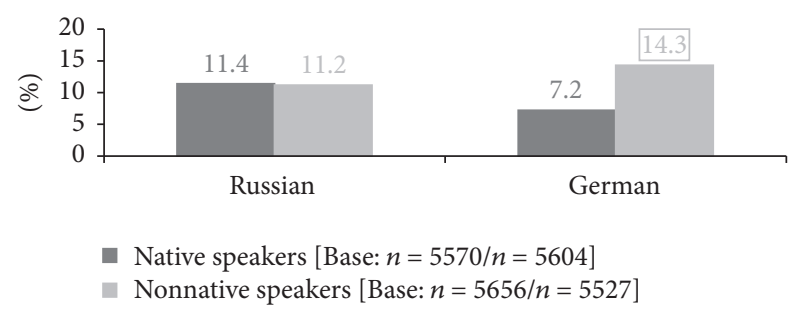

FIGURE 3: Utterance miss (false negative error) for listeners, who are native Russian speakers, depending on the characteristics of the speaker.

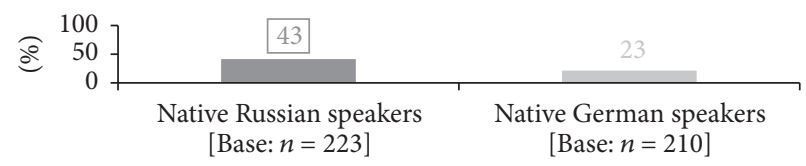

FIgURE 4: Recognition of the word «Поле» (['papə'pifət 'polje], Eng.: «Papa writes to Polya»), depending on the characteristics of the speaker.

TABLE 4: Main substitutes (4\% and more) for phonogram «била» (['bilə], Eng.: «beat»): native Russian speakers at signal-to-noise ratios $=-9$ and $-12 \mathrm{~dB}$ ([Base: $n=90])$.

\begin{tabular}{lccc}
\hline NN & Substitutes & English transcription & Answer share (in \%) \\
\hline 1 & била & ['bilə] & 42 \\
2 & Мила & ['milə] & 6 \\
3 & мыла & ['milə] & 4 \\
4 & хиар & ['hiar] & 4 \\
\hline 5 & 26 substitutes with share 1\%-3\% & 43 \\
\hline
\end{tabular}

Figure 3: a statistically significantly higher (at the level of 95\%) value of utterance miss (false negative error) for German (depending on the characteristics of the speaker) is marked with a frame), which demonstrates the effect of the language (and its acoustic characteristics) of the utterance on detection and recognition of the utterance in noise.

Listeners, who are native speakers of the language of the utterance, are able to detect native speech in noisy environment regardless the speaker's level of proficiency in this language of (see Figure 3); however a foreign accent of the speaker significantly reduces the score of recognition of the utterance language (see Figure 4: a statistically significantly higher (at the level of 95\%) value of recognition (depending on the characteristics of the speaker) of the word «Поле» is marked with a frame), and recognition of the semantic content of the utterance, which confirms findings of experiments $[14,15]$.

Besides, for a number of phonograms with low scores of recognition, the list of these substituting words also differed for speech of native and nonnative speakers: Tables 4 and 5 show most frequent substitutes for the word «била» (['bila'], Eng.: «beat») for phonograms of native and nonnative speakers.

From Tables 4 and 5 we can also see that quite a very wide range of substituting words with low answer shares 
TABLE 5: Main substitutes ( $4 \%$ and more) for phonogram «била» (['bilə], Eng.: «beat»): native German speakers at signal-to-noise ratios $=-9$ and $-12 \mathrm{~dB}$ ([Base: $n=107])$.

\begin{tabular}{lccc}
\hline NN & Substitutes & English transcription & Answer share (in \%) \\
\hline 1 & била & ['bilə] & 34 \\
2 & Зина & ['zinə] & 13 \\
3 & Мила & ['milə] & 13 \\
4 & Дима & ['dimə] & 6 \\
\hline 5 & 28 substitutes with share $1 \%-3 \%$ & 35 \\
\hline
\end{tabular}

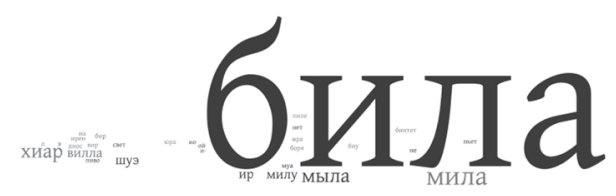

FIGURE 5: «Word cloud» for phonogram «била»: native Russian speakers at signal-to-noise ratios $=-9$ and $-12 \mathrm{~dB}$ [Base: $n=90$ ].

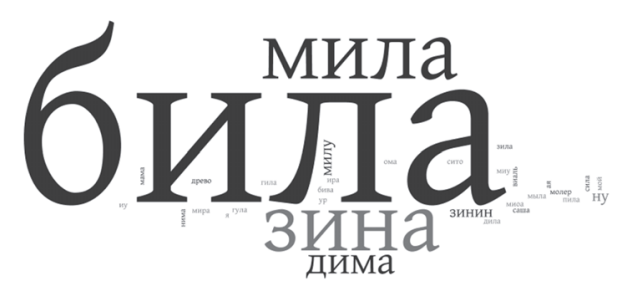

FIGURE 6: «Word cloud» for phonogram «била»: native German speakers at signal-to-noise ratios $=-9$ and $-12 \mathrm{~dB}$ [Base: $n=107]$.

$(1 \%-3 \%)$ was observed for these phonograms: 26 substitutes for phonograms of Russian native speakers and 28 substitutes for phonograms German native speakers and these lists were very different. These varieties of words with low answer shares are visible on the «tag clouds» for these two phonograms (e.g., on Figures 5 and 6). The «tag cloud» or «word cloud» technique was used for analysis of the substituting word frequencies, in which the font size for a particular word was used depending on frequency of its occurrence: the higher the frequency, the greater the font size for a specific word. All the "word clouds" for this experiment were drawn using the online program Wordle ${ }^{\mathrm{TM}}$ [30]. Thus on Figures 5 and 6 we can see lots of small words which are different for both phonograms.

At the acoustic level the degree of the utterance protection also depends on the fundamental frequency of the speaker's voice: within the corpus of the research words and phrases in Russian and German utterances in realizations of males are more concealed from detection against noise (i.e., they demonstrated higher score of utterance miss (false negative error) against noise) than utterances in realizations of females against both tested types of noise with all tested levels of signal-to-noise ratio (see Figures 7 and 8).

At the phonetic level various sounds have various degrees of intelligibility depending on their acoustic nature. Thus, the most resistant (among those tested within the research material of the experiment) to recognition in the stressed syllable are consonants [s] and [m], as well as vowel [a], while



FIGURE 7: Utterance miss (false negative error) for utterances in Russian against pink noise: comparison of male and female voices.

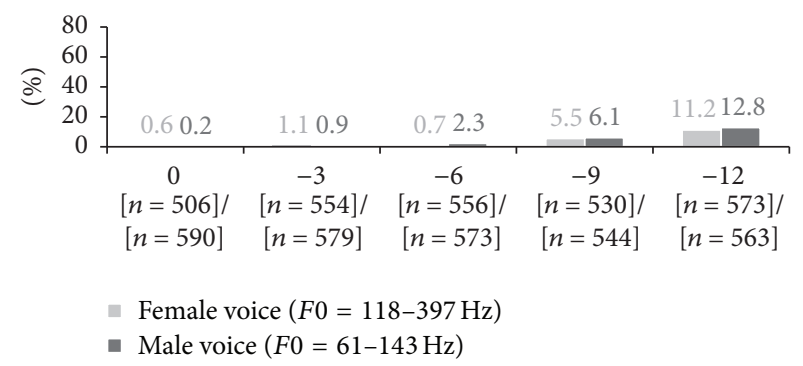

FIGURE 8: Utterance miss (false negative error) for utterances in Russian against white noise: comparison of male and female voices.

the most masked are consonants $[\mathrm{b}]$ and $[\mathrm{p}]$ and vowel [i] (see Figures 9-12).

At the syntactic level correct recognition of words depends on the context: the scores of correct recognition of words, which functioned as a part of a phrase, were higher than the scores for the same words in an isolated position against both tested (pink and white) types of noise at all tested levels of signal-to-noise ratios (see Figures 13 and 14: the data in Figure 13 is sorted in descending order and formatted in MS Excel from the dark colour to the light one).

In the phrases the best recognized parts were subjects (which always came first in the phonogram corpus), with predicates showing the second highest score (see Figures 15 and 16).

At the lexical level recognition of utterances in Russian is influenced by the occurrence of words in the language: within the research corpus of Russian words the highest score of recognition was shown by words «мама», «Саша», and «папа», which have the highest frequency of occurrence in the Russian language among all the tested words, while the lowest scores of recognition were shown by words «Поле», «Зинин», «Борю», and «Милу», which are proper names and less common than «Саша» (see Table 6 index; ipm represents number of occurrences of lemma per one million words in the corpus; here the score is presented according to [31]).

\section{Conclusion}

According to the results of the experiment the following factors influence intelligibility and perception of the speech in noisy environment: 




FIGURE 9: Correct recognition of consonants in first stressed syllable against pink noise.



FIGURE 10: Correct recognition of consonants in first stressed syllable against white noise.

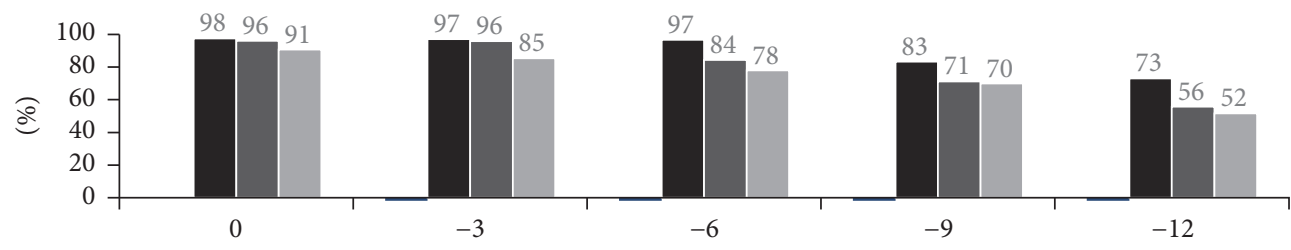

- [a]

- $[\mathrm{o}]$

- [i]

FIGURE 11: Correct recognition of vowels in first stressed syllable against pink noise.

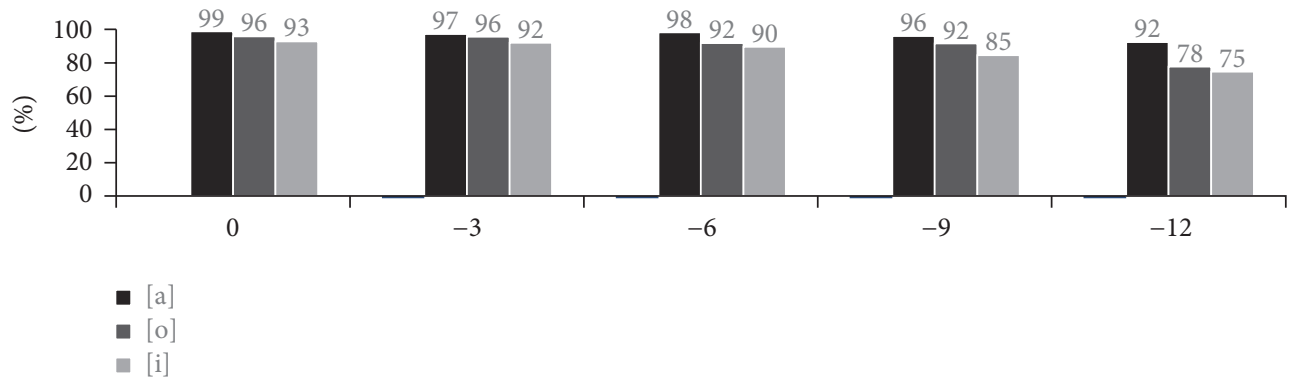

FIGURE 12: Correct recognition of vowels in first stressed syllable against white noise.

(1) Type of noise and signal-to-noise ratio (pink noise provides better protection of the utterance than white noise at equal integral level of signal-to-noise ratio (for all tested levels) in terms of the following indicators: detection of speech signal in noise, correct identification of the utterance language, and correct perception of the semantic content of the utterance);
(2) Utterance language and speaker and listener's proficiency in a specific language;

(3) Fundamental frequency of the speaker's voice (within the corpus of the research material in Russian and German utterances read by males was detected by listeners statistically rarely than utterances read by 


\begin{tabular}{|c|c|c|c|c|c|}
\hline \multirow[b]{2}{*}{ NN } & \multirow[b]{2}{*}{ Word } & \multicolumn{2}{|c|}{ White noise (in \%) } & \multicolumn{2}{|c|}{ Pink noise (in \%) } \\
\hline & & Isolated & $\begin{array}{l}\text { A part of a } \\
\text { phrase }\end{array}$ & Isolated & $\begin{array}{c}\text { A part of a } \\
\text { phrase }\end{array}$ \\
\hline 1 & $\begin{array}{c}\text { Саша } \\
(\text { Eng.: «Sasha») }\end{array}$ & 89 & 97 & 83 & 92 \\
\hline 2 & $\begin{array}{c}\text { папа } \\
\text { (Eng.: «Father») }\end{array}$ & 87 & 94 & 73 & 89 \\
\hline 3 & $\begin{array}{c}\text { сушит } \\
\text { (Eng.: } « \text { dries») }\end{array}$ & 84 & 91 & 81 & 86 \\
\hline 4 & $\begin{array}{c}\text { сито } \\
\text { (Eng.: «sieve») }\end{array}$ & 73 & 92 & 71 & 86 \\
\hline 5 & $\begin{array}{c}\text { баба } \\
\text { (Eng.: «Woman») }\end{array}$ & 79 & 88 & 62 & 76 \\
\hline 6 & $\begin{array}{c}\text { моет } \\
\text { (Eng.: «washes») }\end{array}$ & 77 & 84 & 69 & 75 \\
\hline 7 & $\begin{array}{c}\text { била } \\
\text { (Eng.: «beat») }\end{array}$ & 56 & 88 & 39 & 76 \\
\hline 8 & $\begin{array}{c}\text { Милу } \\
\text { (Eng.: «Milu») }\end{array}$ & 55 & 79 & 47 & 71 \\
\hline 9 & $\begin{array}{c}\text { Борю } \\
\text { (Eng.: «Boryu») }\end{array}$ & 52 & 84 & 41 & 72 \\
\hline 10 & $\begin{array}{c}\text { Поле } \\
\text { (Eng.: «Polye») }\end{array}$ & 38 & 61 & 27 & 54 \\
\hline
\end{tabular}

FIGURE 13: Comparative analysis of correct recognition of words in Russian against various types of noise in various context (isolated words or as a part of a phrase), in \%.

\begin{tabular}{cccccc}
\hline N & $\begin{array}{c}\text { Signal-to-noise } \\
\text { ratio }\end{array}$ & \multicolumn{2}{c}{ White noise } & \multicolumn{2}{c}{ Pink noise } \\
Isolated & $\begin{array}{c}\text { A part of a } \\
\text { phrase }\end{array}$ & Isolated & $\begin{array}{c}\text { A part of a } \\
\text { phrase }\end{array}$ \\
\hline 1 & $0 \mathrm{~dB}$ & 1 & 0 & 1 & 0 \\
2 & $-3 \mathrm{~dB}$ & 1 & 0 & 3 & 0 \\
3 & $-6 \mathrm{~dB}$ & 3 & 0 & 5 & 1 \\
4 & $-9 \mathrm{~dB}$ & 4 & 0 & 9 & 2 \\
5 & $-12 \mathrm{~dB}$ & 8 & 2 & 14 & 10 \\
\hline
\end{tabular}

FIGURE 14: Number of tested words (from 15), the score of recognition of which did not exceed 50\% at each level of signal-to-noise ratio.



Figure 15: Recognition of isolated words in the phrase «Папа пишет Поле» (Eng.: Father writes to Polya) against white noise [Base: $n=252]$.

females against both tested types of noise with all levels of signal-to-noise ratio);

(4) Context: isolated word or as a part of the phrase (within the corpus of the research material in Russian intelligibility of words within the phrase was better against both tested types of noise with all levels of signal-to-noise ratio compared to isolated words);



FIgURE 16: Recognition of isolated words in the phrase «Папа пишет Поле» (Eng.: Father writes to Polya) against pink noise [Base: $n=247]$.

(5) Frequency of word occurrence in the language (according to the results of the experiment, words with higher frequency of occurrence in the Russian language showed better intelligibility);

(6) Phonetic composition of the word (within the corpus of the research material in Russian the voiceless sibilant fricative alveolar [s] and sonorant bilabial [m] among consonants and central open [a] among 
TABLE 6: Frequency of occurrence in the Russian language of the tested words with the highest and the lowest scores of recognition (according to the results of the current experiment).

\begin{tabular}{lcc}
\hline $\mathrm{N}$ & Word & $\begin{array}{c}\text { ipm } \\
\text { (number of occurrences of lemma per } \\
\text { one million word) }\end{array}$ \\
\hline 1 & мама (Eng.: «mother») & 322,6 \\
2 & Саша (Eng.: «Sasha») & 93,6 \\
3 & папа (Eng.: «father») & 143,4 \\
\hline 4 & Милу (Eng.: «Milu») & 10 \\
5 & Борю (Eng.: «Boryu») & 19,6 \\
6 & Зинин (Eng.: «Zina»s») & 20,8 \\
7 & Поле (Eng.: «Polye») & 8,1 \\
\hline
\end{tabular}

vowels showed the best intelligibility (i.e., the worst ability of masking using noise) within the tested set of sounds, while among consonants stop bilabial ones: voiced [b] and voiceless [p] and front close [i] among vowels showed the worst intelligibility, that is, the best ability of masking using noise).

Among the further possible directions of analysis the following can be mentioned:

(1) Increase of volume of bilingual research material;

(2) Expansion of the inventory of acoustic parameters for the analysis of the language sounds recognition;

(3) Increase of the number of speakers and listeners taking into account such factors as age, gender, degree of experience in listening, and proficiency in the utterance language, in relation to the studied languages;

(4) Study of the influence of linguistic and extralinguistic factors on the recognition in noisy environment for long connected texts;

(5) Organization of the database, including units of the sound composition and intonation system of various languages.

\section{Conflicts of Interest}

The authors declare that they have no conflicts of interest.

\section{Acknowledgments}

The research was supported by Ministry of Education and Science of Russian Federation (Project no. 34.1254.2014K, head of the project R. K. Potapova).

\section{References}

[1] S. Anderson, E. Skoe, B. Chandrasekaran, S. Zecker, and N. Kraus, "Brainstem correlates of speech-in-noise perception in children," Hearing Research, vol. 270, no. 1-2, pp. 151-157, 2010.

[2] S. Anderson, A. Parbery-Clark, H.-G. Yi, and N. Kraus, "A neural basis of speech-in-noise perception in older adults," Ear and Hearing, vol. 32, no. 6, pp. 750-757, 2011.
[3] J. Cunningham, T. Nicol, S. G. Zecker, A. Bradlow, and N. Kraus, "Neurobiologic responses to speech in noise in children with learning problems: deficits and strategies for improvement," Clinical Neurophysiology, vol. 112, no. 5, pp. 758-767, 2001.

[4] D. Poeppel, W. J. Idsardi, and V. Van Wassenhove, "Speech perception at the interface of neurobiology and linguistics," Philosophical Transactions of the Royal Society B: Biological Sciences, vol. 363, no. 1493, pp. 1071-1086, 2008.

[5] J. H. Song, E. Skoe, K. Banai, and N. Kraus, "Training to improve hearing speech in noise: biological mechanisms," Cerebral Cortex, vol. 22, no. 5, pp. 1180-1190, 2012.

[6] K. D. R. Drager and J. E. Reichle, "Effects of discourse context on the intelligibility of synthesized speech for young adult and older adult listeners: applications for AAC," Journal of Speech, Language, and Hearing Research, vol. 44, no. 5, pp. 1052-1057, 2001.

[7] S. King, J. Yamagishi, and C. Valentini-Botinhao, "Evaluating speech intelligibility enhancement for HMM-based synthetic speech in noise," in Proceedings of the SAPA-SCALE Workshop on Statistical and Perceptual Audition (SAPA-SCALE '12), Portland, Ore, USA, 2012.

[8] S. Kamath and P. Loizou, "A multi-band spectral subtraction method for enhancing speech corrupted by colored noise," in Proceedings of the IEEE International Conference on Acoustics, Speech, and Signal Processing (ICASSP '02), vol. 4, pp. 41604164, Orlando, Fla, USA, May 2002.

[9] G. Kim, Y. Lu, Y. Hu, and P. C. Loizou, "An algorithm that improves speech intelligibility in noise for normal-hearing listeners," Journal of the Acoustical Society of America, vol. 126, no. 3, pp. 1486-1494, 2009.

[10] N. Zoghlami and Z. Lachiri, "Application of perceptual filtering models to noisy speech signals enhancement," Journal of Electrical and Computer Engineering, vol. 2012, Article ID 282019, 12 pages, 2012.

[11] A. Parbery-Clark, E. Skoe, C. Lam, and N. Kraus, "Musician enhancement for speech-in-noise," Ear and Hearing, vol. 30, no. 6, pp. 653-661, 2009.

[12] J. Slater, E. Skoe, D. L. Strait, S. O'Connell, E. Thompson, and N. Kraus, "Music training improves speech-in-noise perception: longitudinal evidence from a community-based music program," Behavioural Brain Research, vol. 291, pp. 244-252, 2015.

[13] M. Pinet, P. Iverson, and B. G. Evans, "Perceptual adaptation for 11 and 12 accents in noise by monolingual British English listeners," in Proceedings of the 17th International Congress of Phonetic Sciences, Hong Kong, August 2011.

[14] M. J. Munro and T. M. Derwing, "Foreign accent, comprehensibility, and intelligibility in the speech of second language learners," Language Learning, vol. 49, no. 1, pp. 285-310, 1999.

[15] M. J. Munro, "The effects of noise on the intelligibility of foreign-accented speech," Studies in Second Language Acquisition, vol. 20, no. 2, pp. 139-154, 1998.

[16] J. Song and P. Iverson, "Measuring speech-in-noise intelligibility for spontaneous speech: the effect of native and non-native accents," in Proceedings of the 18th International Congress of Phonetic Sciences, Glasgow, UK, August 2015.

[17] T. Bent and A. R. Bradlow, "The interlanguage speech intelligibility benefit," Journal of the Acoustical Society of America, vol. 114, no. 3, pp. 1600-1610, 2003.

[18] Y. S. Bykov, Theory of speech intelligibility and improving the efficiency of telephone communications, Moscow, Russia, 1959 (Russian). 
[19] N. B. Pokrovskiy, "Calculation and measurement of speech intelligibility," Moscow, 1962 (Russian).

[20] M. A. Sapozhkov, "Speech signal in cybernetics and communication," Moscow, 1963 (Russian).

[21] L. V. Zlatoustova, R. K. Potapova, V. V. Potapov, and V. N. Trunin-Donskoy, General and Applied Phonetics: Textbook, MSU, Moscow, Russia, 2nd edition, 1997 (Russian).

[22] R. K. Potapova and O. N. Statsenko, "Preliminary results of the investigation of oral speech material considering codeswitching," in Proceedings of the 16th Session of the Russian Acoustical Society, Moscow, Russia, November 2005.

[23] R. Potapova and V. Potapov, "Associative mechanism of foreign language perception (forensic phonetic aspect)," in Proceedings of the Speech and Computer. SPECOM 2014, A. Ronzhin, R. Potapova, and V. Delic, Eds., vol. 8773 of Lecture Notes in Computer Science, pp. 113-122, Springer International Publishing, Cham, Switzerland, 2014.

[24] R. Potapova and V. Potapov, "Cognitive mechanism of semantic content decoding of spoken discourse in noise," in Proceedings of the Speech and Computer. SPECOM 2015, A. Ronzhin, R. Potapova, and N. Fakotakis, Eds., vol. 9319 of Lecture Notes in Computer Science, pp. 153-160, Springer Internartional Publishing, Cham, Switzerland, 2015.

[25] R. K. Potapova, "Syllabic phonetics of the Germanic languages: textbook," Moscow, 1986 (Russian).

[26] R. K. Potapova, Speech: Communication, Information, Cybernetics, Moscow, Russia, 4th edition, 2010 (Russian).

[27] Council of Europe, Common European Framework of Reference for Languages: Learning, Teaching, Assessment (CEFR), http://www.coe.int/t/dg4/linguistic/Source/Framework_EN .pdf.

[28] O. V. Ivanov, "Statistics/Training course for sociologists and managers. Part 2. Confidence intervals. Hypothesis testing. Methods and their application," Moscow, 2005 (Russian).

[29] N. Sh. Kremer, Probability Theory and Mathematical Statistics: Textbook for Universities, Moscow State University, Moscow, Russia, 2nd edition, 2004 (Russian).

[30] Online program for creating "word clouds" Wordle ${ }^{\mathrm{TM}}$, http:// www.wordle.net.

[31] O. N. Lyashevskaya and S. A. Sharov, New frequency dictionary of Russian vocabulary. The Frequency dictionary of modern Russian language (on the materials of the National corpus of the Russian language), (Russian), http://dict.ruslang.ru/freq.php. 




\section{Enfincering}
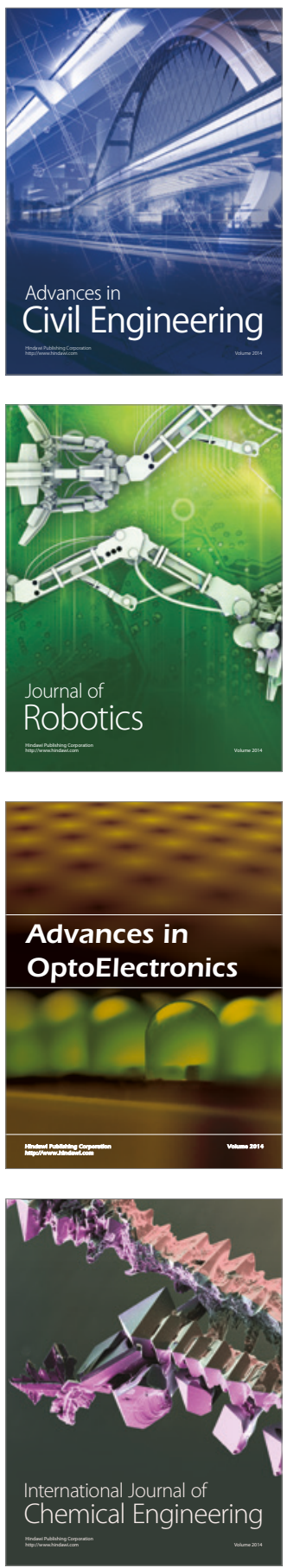

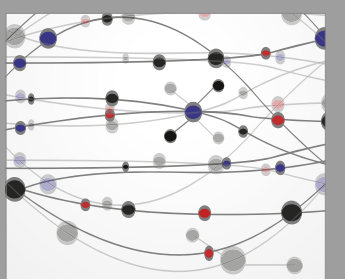

The Scientific World Journal



\section{Hindawi}

Submit your manuscripts at

https://www.hindawi.com
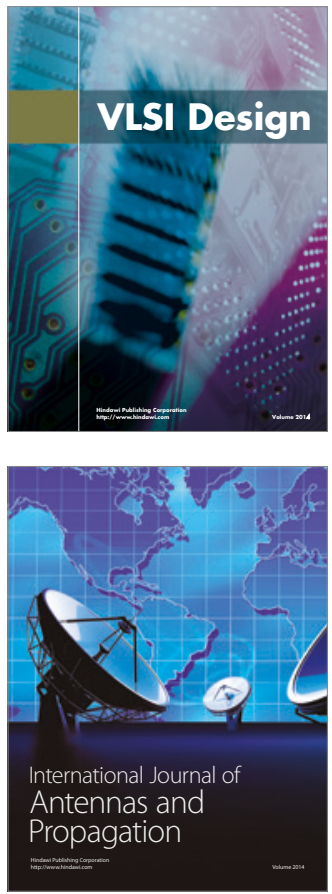

\section{Rotating}

Machinery
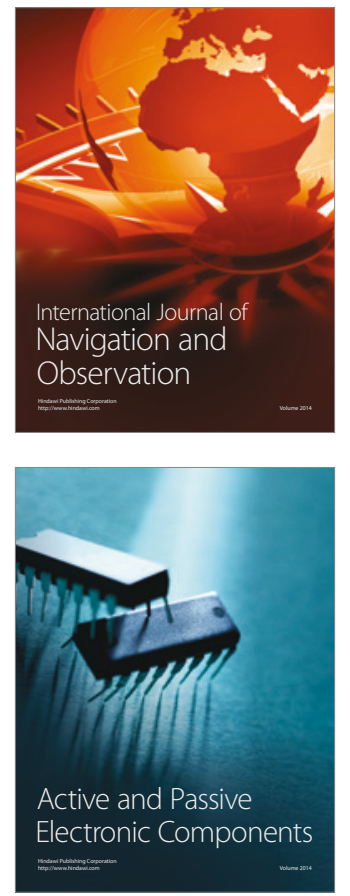
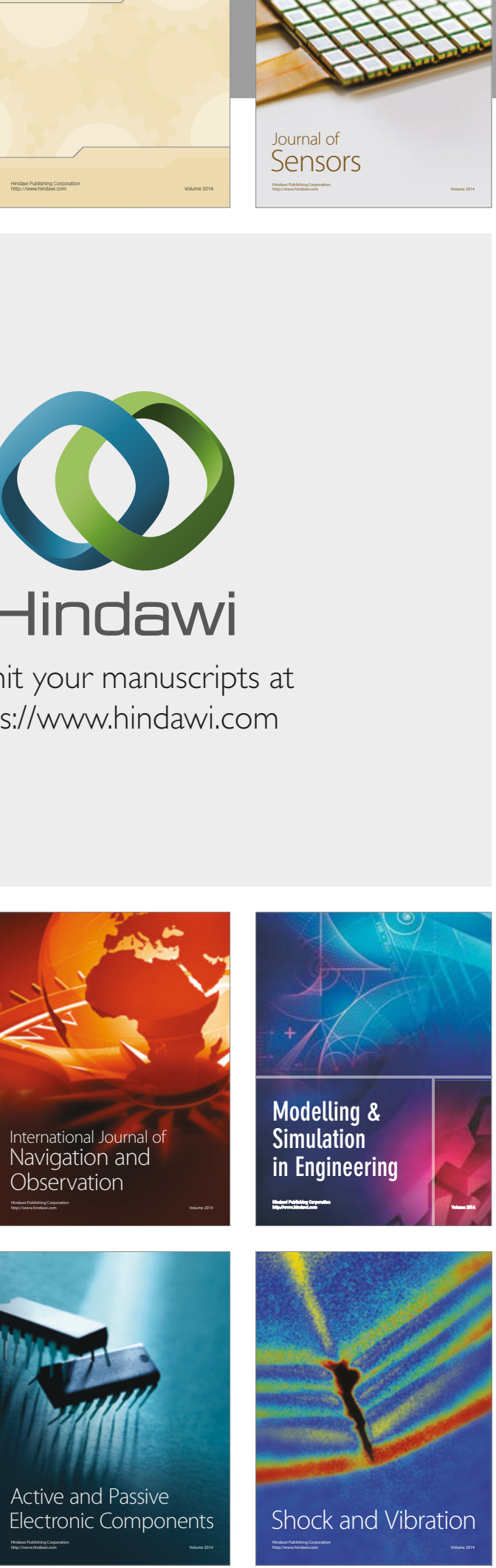
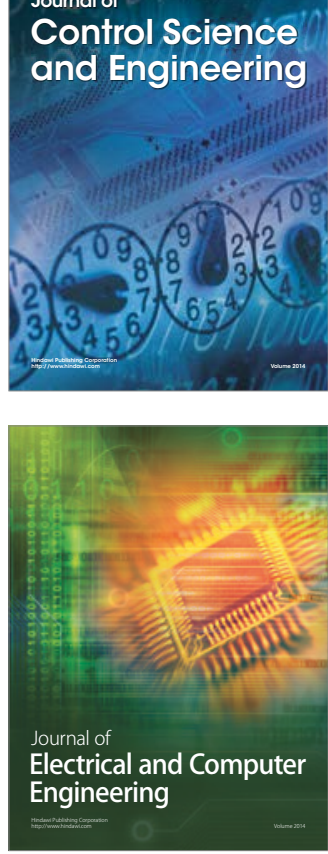

Distributed

Journal of

Control Science

and Engineering
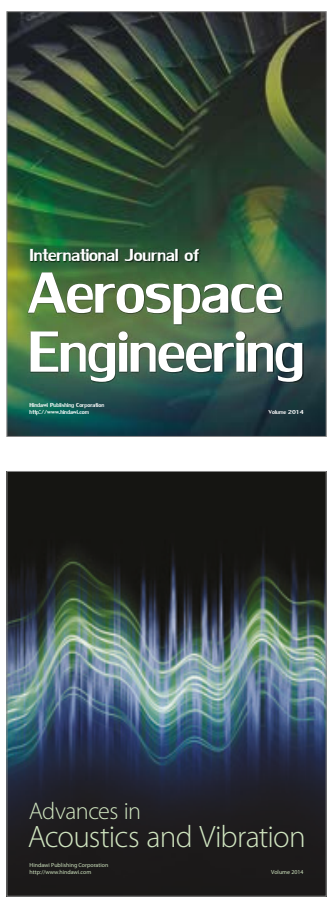

Sensor Networks 